\title{
ОПЫТ ИСПОЛЬЗОВАНИЯ НАНОЧАСТИЦ ГИДРОКСИДА ЖЕЛЕЗА ПРИ РАЗМНОЖЕНИИ RIBES NIGRUM L. ЗЕЛЕНЫМИ ЧЕРЕНКАМИ
}

\section{N.A. Mistratova, Yu.L. Gurevich,} M.I. Teremova, A.A. Kolesnik

\section{THE EXPERIENCE OF USING IRON HYDROXIDE NANOPARTICLES WHILE REPRODUCING RIBES NIGRUM L. BY GREEN SHANKS}

Мистратова Н.A. - канд. с.-х. наук, доц. каф. растениеводства, селекции и семеноводства Красноярского государственного аграрного университета, г. Красноярск.

E-mail: mistratova@mail.ru

Гуревич Ю.Л. - д-р физ.-мат. наук, гл. науч. сотр. Международного научного центра исследований экстремальных состояний организма ФИЦ «Красноярский научный центр СО РАН», г. Красноярск.

E-mail: btchem@mail.ru

Теремова М.И. - вед. инженер Международного научного центра исследований экстремальных состояний организма ФИЦ «Красноярский научный центр СО РАН», г. Красноярск.

E-mail: mterem@mail.ru

Колесник А.А. - асп. каф. почвоведения и агрохимии, директор Научно-исследовательского испытательного центра Красноярского государственного аграрного университета, г. Красноярск.

E-mail: airlexxx@mail.ru

Представлены результаты применения при размножении смородины черной (Ribes nigrum L.) зелеными черенками растворов индолил-3-уксусной кислоты и этого же раствора с введением трех модифрикаций наночастии биогенного гидроксида железа. Испытаны коллоидные наночастицы «чистого» ферригидрита (Feh) и ферригидрита, допированного алюминием (Feh_Al) и кобальтом (Feh_Co). При обработке черенков раствором ИУК+Fеh_Со процент окоренения составил 100 \%. Добавление к стимулятору Feh и фрерригидрита, допированного алюминием (ИУК+Feh_Al), повлекло снижение показателя корнеобразования - 47 и $73 \%$ соответственно. Учет биометрических параметров на второй год исследований при
Mistratova N.A. - Cand. Agr. Sci., Assoc. Prof., Chair of Plant Growing, Selection and Seed Farming, Krasnoyarsk State Agrarian University, Krasnoyarsk.

E-mail:mistratova@mail.ru

Gurevich Yu.L. - Dr. Phys.-Math. Sci., Chief Staff Scientist, International Scientific Center of Researches of Extreme Conditions of an Organism, FRC "Krasnoyarsk Scientific Center SB RAS", Krasnoyarsk.

E-mail: btchem@mail.ru

Teremova M.I. - Leading Engineer, International Scientific Center of Researches of Extreme Conditions of an Organism, FRC "Krasnoyarsk Scientific Center SB RAS", Krasnoyarsk.

E-mail: mterem@mail.ru

Kolesnik A.A. - Post-Graduate Student, Chair of Soil Science and Agrochemistry, Director, Research Test Center, Krasnoyarsk State Agrarian University, Krasnoyarsk.

E-mail: airlexxx@mail.ru

выкопке саженцев показал, что среднее количество побегов на вариантах с применением суспензий наночастиц ниже либо на уровне контроля. Использование Feh незначительно повьсило среднее количество побегов - 3,4 шт. При учете средней длины побегов отмечено увеличение данного показателя на всех вариантах опыта с применением биогенного ферригидрита - 41,9-52,7 см. Больший процент стандартных саженцев получен при использовании растворов наночастиц - 75-100 \% растений 1-го и 2-го товарных сортов. Среди изучаемых модификаций наночастии гидроксида железа выделился вариант ИУК+Feh_Co, с использованием которого процент окоренения и качество посадочного материала были 
наибольшими по сравнению с контролем и другими вариантами опыта: ризогенез составил $100 \%$, выход саженцев товарных сортов $81,3 \%$, из них $50 \%$ - 1-й copm и 31,3\% - 2-й copm. Эфффективность наночастии Feh u Feh_Al может быть увеличена путем подбора концентраций и времени экспозиции черенков в растворах с индолил-3-уксусной кислотой.

Ключевые слова: смородина черная, зеленые черенки, гидроксид железа, наночастицы, окоренение, биометрические параметры, качество саженцев.

The results of application of the propagation of black currant (Ribes nigrum L.) with green cuttings of solutions of indolyl-3-acetic acid and the same solution with the introduction of three modifications of biogenic iron hydroxide nanoparticles are presented. Colloidal nanoparticles of "pure" ferrihydrite (Feh) and ferrihydrite doped with aluminum (Feh_Al) and cobalt (Feh_Co) were tested. When processing cuttings with the solution of IAA + Feh_Co, the percentage of rooting was $100 \%$. The addition of Feh and ferrihydrite doped with aluminum (IAA + Feh_Al) to the stimulator resulted in the decrease in root formation index $-47 \%$ and $73 \%$, respectively. The account of biometric parameters in the second year of the research at digging seedlings showed that average number of shoots for options using suspensions of nanoparticles was lower, or at the control level. Using Feh slightly increased average number of shoots - 3.4 pcs. When taking into account average shoot length, the increase of this indicator was noted in all experimental variants using biogenic ferrihydrite - 41.9-52.7 cm. A larger percentage of standard seedlings was obtained using solutions of nanoparticles - 75-100 \% of the plants of the 1st and 2nd commodity varieties. Among studied modifications of iron hydroxide nanoparticles, IAA + Feh_Co variant stood out, with its using rooting percentage and the quality of planting material were the highest compared to the control and other experimental options: rhizogenesis was $100 \%$, the yield of seedlings of commercial varieties was $81.3 \%$ of them $50 \%$ were 1-st grade and $31.3 \%$ - 2-nd grade. The efficiency of Feh and Feh_Al nanoparticles can be increased by selecting the concentrations and exposure time of cuttings in the solutions with indolyl-3acetic acid.

Keywords: black currant, green cuttings, iron hydroxide, nanoparticles, rooting, biometric parameters, seedlings quality.
Введение. Нанотехнологии и наноматериалы находят применение практически во всех областях сельского хозяйства, в том числе и в растениеводстве. Использование нанопрепаратов в садоводстве повышает урожайность плодовых и ягодных культур, обеспечивает их устойчивость к неблагоприятным погодным условиям [1]. Исследований по изучению действия наночастиц в практике питомниководства недостаточно [2, 3].

Размножение зелеными черенками - один из наиболее перспективных способов вегетативного размножения, позволяющий получать корнесобственные растения в промышленных масштабах [4].

Смородина черная пользуется популярностью среди населения Сибири, так как отличается зимостойкостью, скороплодностью, урожайностью, а также богатым витаминным составом ягод [5]. Поэтому совершенствование технологии ее размножения актуально.

Цель исследования: использование наночастиц биогенного гидроксида железа на размножение Ribes nigrum L. зелеными черенками [6].

Объекты и методы исследования. Опыт проведен в 2017-2018 гг. на участке размножения ООО «Садовый центр Аграрного университета». Черенки окореняли в условиях мелкокапельного полива, светопрозрачное ограждение поликарбонат. Доращивание окорененных черенков (2018 год) в условиях открытого грунта осуществляли на фитоучастке кафедры растениеводства, селекции и семеноводства. Объекты исследований - смородина черная (Ribes nigrum L.), сорт Сокровище, и наночастицы биогенного ферригидрита.

Зеленые черенки замачивали в растворе индолил-3-уксусной кислоты (ИУК) и наночастиц биогенного гидроксида железа в трех модификациях. Варианты опыта:

1) контроль - обработка черенков индолил-3уксусной кислотой (ИУК);

2) ИУК + ферригидрит (ИУК+Feh);

3) ИУК + ферригидрит, допированный алюминием (ИУК+Feh_Al);

4) ИУК + ферригидрит, допированный Со (ИУК+Feh_Co).

В растворы для замачивания черенков вносили ИУК (0,07 \% на 1 л) и наночастицы (1 мг/л). Экспозиция обработки черенкового материала 24 часа. Схема посадки $7 \times 7$ см. Повторность опыта 3-кратная, размещение вариантов систематическое. Размножение зелеными черенками 
и учет биометрических показателей проводили по общепринятым методикам $[7,8]$. Учет окоренения черенков осуществляли в третьей декаде сентября. Качество посадочного материала определяли в соответствии ГОСТ Р 53135-2008 [9]. Лабораторный анализ почвенных образцов проводился согласно ГОСТам в Научноисследовательском центре ФГБОУ ВО Красноярский ГАУ. Выполнялись следующие виды анализов почвенных образцов: определение $\mathrm{pH}$ водной суспензии по ГОСТ 26423-85 [10]; определение содержания нитратного азота - по методу ЦИНАО (ГОСТ 26488-85) [11]; определение обменного аммония по методу ЦИНАО (ГОСТ 26489-85) [12]; определение подвижного фосфора и обменного калия - по методу Чирикова в модисикации ЦИНАО (ГОСТ 26204-91) [13]. Математическая обработка результатов исследований проведена методом дисперсионного анализа с использованием компьютерной программы MS Excel [14].

Результаты исследования. Лучший показатель ризогенеза черенков (100 \%) при использовании растворов наночастиц отмечен на варианте ИУК+Fe_Co, что на уровне контроля (puc. 1).

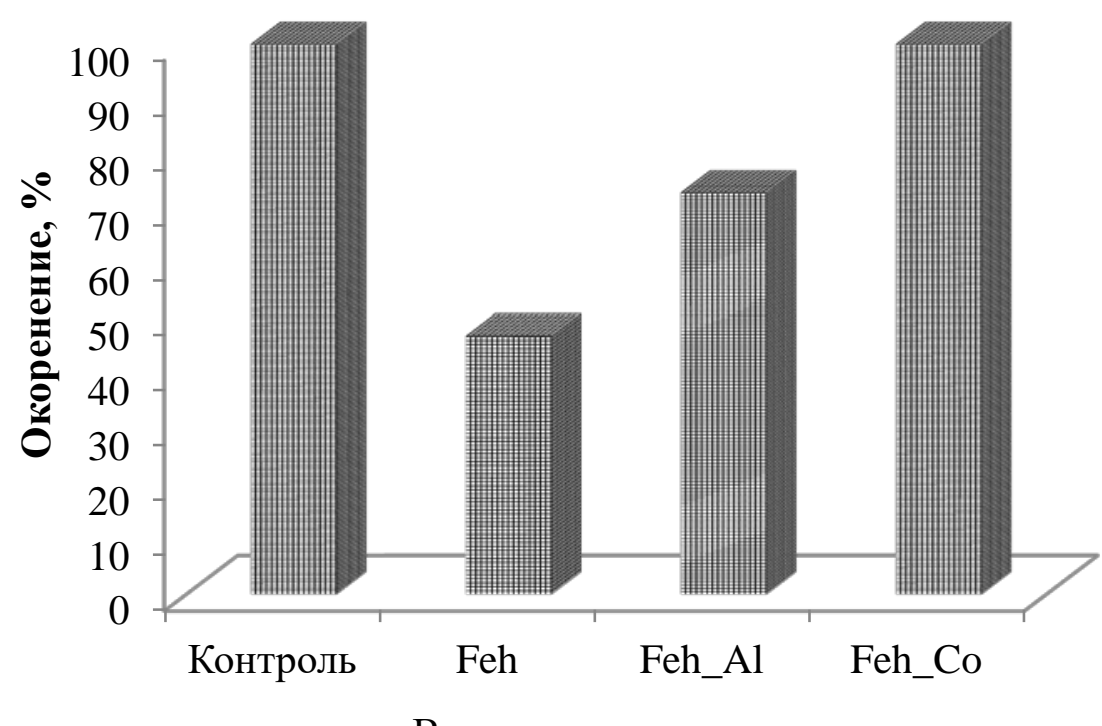

Варианты опыта

Puc. 1. Влияние растворов наночастиц на окоренение зеленых черенков смородины черной, 2017 г.

При добавлении к стимулятору «чистого» ферригидрита (ИУК+Feh) и ферригидрита, допированного алюминием (ИУК+Feh_Al), прослеживается снижение показателя корнеобразования - процент окоренения составил 47 и $73 \%$ соответственно, что ниже контрольной делянки на 53 и $27 \%$.

При обработке черенков раствором ИУК+Feh_Со отмечено лучшее развитие корневой системы, где в среднем на черенке сфрормировалось по 60 корешков первого порядка ветвления длиною 4 см. Длина поглощающей поверхности в 2,1 раз превышает показатели контрольных черенков, что позволяет повысить морфометрические показатели и, соответственно, товарность посадочного материала в следующий вегетационный период. При использовании наночастиц модификаций Feh и Feh_Al морфометрические параметры черенков, кроме количества побегов, были ниже контрольного варианта (табл. 1, рис. 2) .

При замачивании стеблевых черенков в течение 24 часов выделился вариант ИУК+ферригидрит, допированный Со (окоренение $100 \%$ ), морфометрические показатели корневой системы при использовании данного раствора достоверно превысили контроль. 
Морфометрические параметры окорененных черенков, 2017 г.

\begin{tabular}{|l|c|c|c|c|}
\hline \multicolumn{1}{|c|}{ Вариант } & $\begin{array}{c}\text { Кол-во корней } \\
\text { 1-го порядка } \\
\text { ветвления, шт. }\end{array}$ & $\begin{array}{c}\text { Суммарная длина корней } \\
\text { 1-го порядка ветвления, } \\
\text { см }\end{array}$ & $\begin{array}{c}\text { Кол-во побе- } \\
\text { гов, шт. }\end{array}$ & $\begin{array}{c}\text { Суммарная } \\
\text { длина побе- } \\
\text { гов, см }\end{array}$ \\
\hline 1. Контроль & 33,4 & 113 & 1 & 14 \\
\hline 2. ИУК+Feh & 15,7 & 90,5 & 2 & 12 \\
\hline 3. ИУК+Feh_Al & 30,0 & 100 & 2 & 12,5 \\
\hline 4. ИУК+Feh_Co & 58,4 & 240 & 0 & 0 \\
\hline HСР05 & 9,5 & 16,1 & 0,9 & 5,8 \\
\hline
\end{tabular}
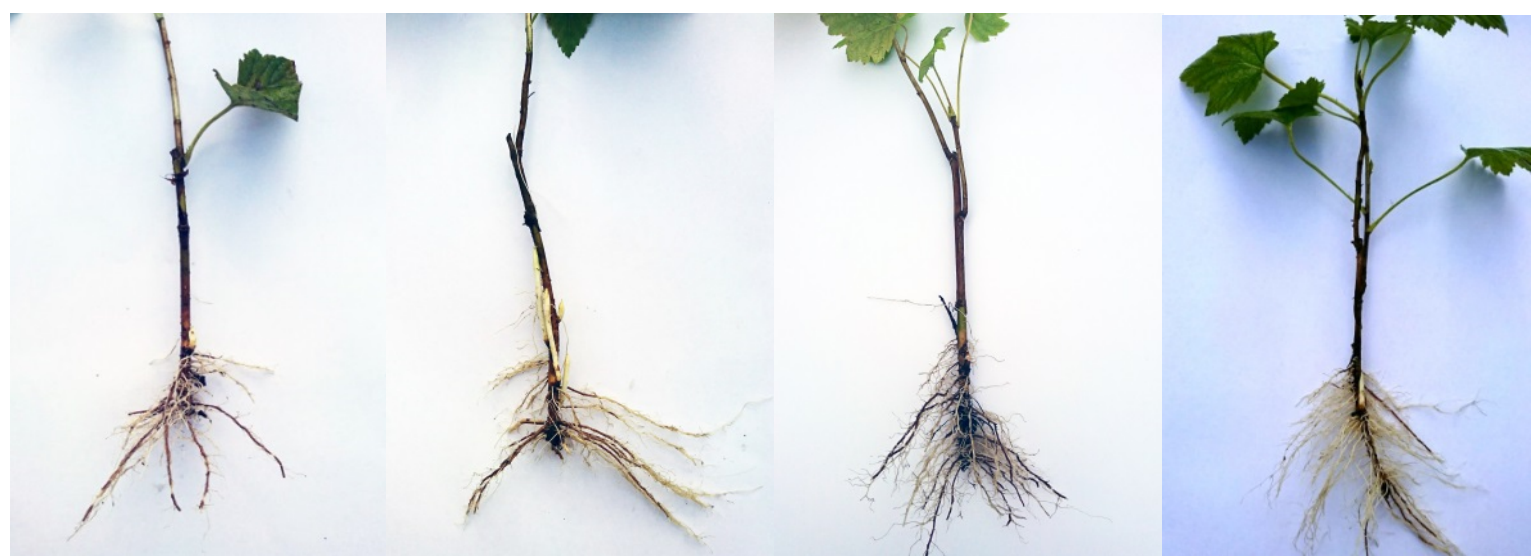

Контроль ИУК+Feh ИУК+Feh_Al ИУК+Feh_Сo

Puс. 2. Морфометрические параметры окорененных черенков, май 2018 2.

На второй год исследований (2018 г.) саженцы доращивались в условиях открытого грунта на фитоучастке кафедры растениеводства, селекции и семеноводства (мкр. Ветлужанка г. Красноярска).

Все месяцы вегетационного периода 2018 г. характеризовались теплой погодой. В июне, августе и сентябре среднемесячная температура воздуха составила 19,$8 ; 18,0 ; 10,3^{\circ} \mathrm{C}$ соответственно, что выше среднемноголетней на 4,2; 2,7 и $1,3{ }^{\circ} \mathrm{C}$. Май и июль отличились незначительным недостатком тепла, отклонение в мае от среднемноголетних показателей составило $1,4^{\circ} \mathrm{C}$, в июне $-0,7^{\circ} \mathrm{C}$.

Недостаток влаги в течение вегетационного периода от 3,3 мм в мае до 13,9 мм в июле при умеренно теплой погоде не оказал негативного влияния на развитие саженцев смородины.

Агрохимическая характеристика почвы представлена в таблице 2.

Таблица 2

Агрохимические показатели почвы

\begin{tabular}{|c|c|c|c|c|c|}
\hline \multirow{2}{*}{ рН водн. } & \multirow{2}{*}{ Гумус, \% } & $\begin{array}{c}\text { Азот } \\
\text { нитратный }\end{array}$ & $\begin{array}{c}\text { Азот } \\
\text { аммонийный }\end{array}$ & $\begin{array}{c}\text { Калий } \\
\text { по Чирикову }\end{array}$ & $\begin{array}{c}\text { Фоссоор } \\
\text { по Чирикову }\end{array}$ \\
\cline { 3 - 6 } & \multicolumn{4}{|c|}{ мг/кГ } \\
\hline 7,95 & 13,81 & 14,5 & 19,3 & 117,4 & 437,3 \\
\hline
\end{tabular}

Гумус - основная биохимическая составляющая почвы, которая является питательной средой для растений и развития полезных микроорганизмов. Содержание гумуса в почве опытного участка составляет $13,81 \%$, что сви- детельствует об очень высокой степени его содержания.

Для оптимального развития окорененных черенков смородины черной одним из основных агроэкологических фракторов является ней- 
тральная реакция почвы. При соблюдении этого условия корневая система лучше развивается, в результате чего перезимовка саженцев в условиях Сибири проходит без негативных последствий. На участке доращивания окорененных черенков величина рН водн. почвы составило 7,95 единиц, что говорит о слабощелочной реакции.

В исследованиях $[15,16]$ отмечено, что основной формой азота, используемого для питания растений, является нитратная. Именно по количеству этой формы можно судить о степени обеспеченности растений азотом и строить прогнозы по поводу необходимости внесения азотных удобрений, а также определять оптимальные их дозы. П.С. Бугаков и В.В. Чупрова отмечают, что азот нитратов и обменного аммония в физиологическом отношении является равноценным источником азотного питания для растений [17].

Содержание нитратного азота в почве на опытных делянках составляет 14,5 мг/кг, что соответствует четвертому классу, т. е. повышенной обеспеченности.

Количество аммонийного азота высокое, оно составляет 19,3 мг/кг почвы и свидетельствует о высокой степени обеспеченности этой формой азота.

Содержание подвижных почвенных фоссратов составляет 437,3 мг/кг, что свидетельствует об очень высоком классе обеспеченности почвы этим важнейшим элементом питания. Количество обменного калия равно 117,4 мг/кг, что соответствует средней степени обеспеченности почвы данным элементом.

В целом агрохимический фон при доращивании саженцев смородины черной в открытом грунте свидетельствует о высоком плодородии почвы по комплексу показателей и отвечает требованиям при возделывании данной культуры.

Для определения соотношения стандартной и нестандартной продукции смородины черной проведена оценка следующих показателей: средняя высота саженцев, среднее количество разветвлений на саженец (число побегов), количество и длина основных корней, длина основных корней (рис. 3-5).

Среднее количество побегов на вариантах с применением суспензий наночастиц ниже (ИУК+Feh_Al - 1,8 шт.) либо на уровне контроля (ИУК+Feh_Co - 3,1 шт.). Применение Feh незначительно повысило среднее количество побегов - 3,4 шт.

При учете средней длины побегов отмечено увеличение данного показателя на всех вариантах опыта с использованием биогенного ферригидрита - 41,9-52,7 см, что выше относительно контроля на 8,3-19,1 см.

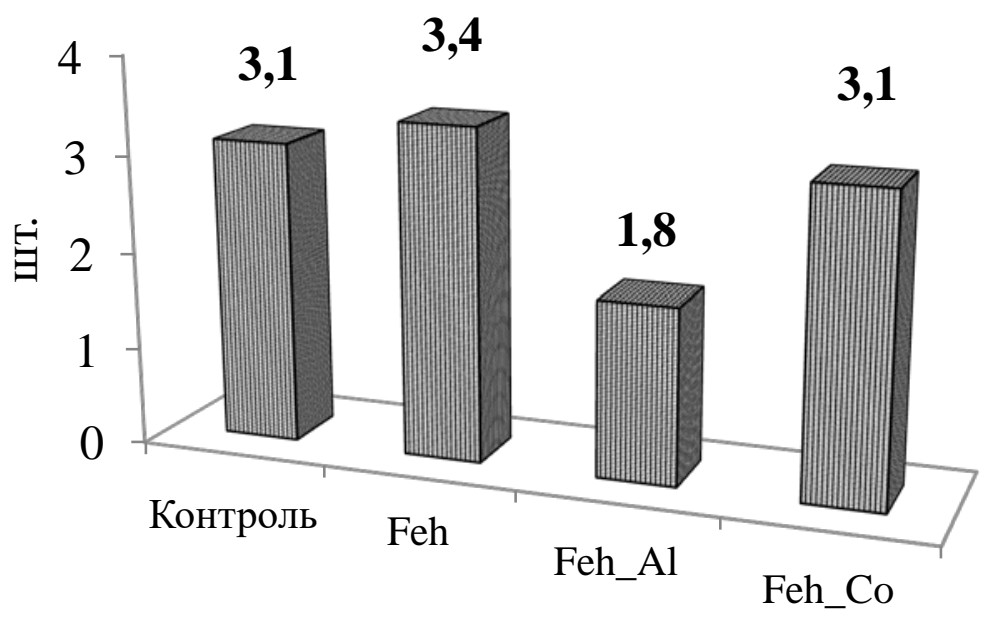

Варианты опыта

Pис. 3. Среднее количество побегов, сентябрь 2018 г. 


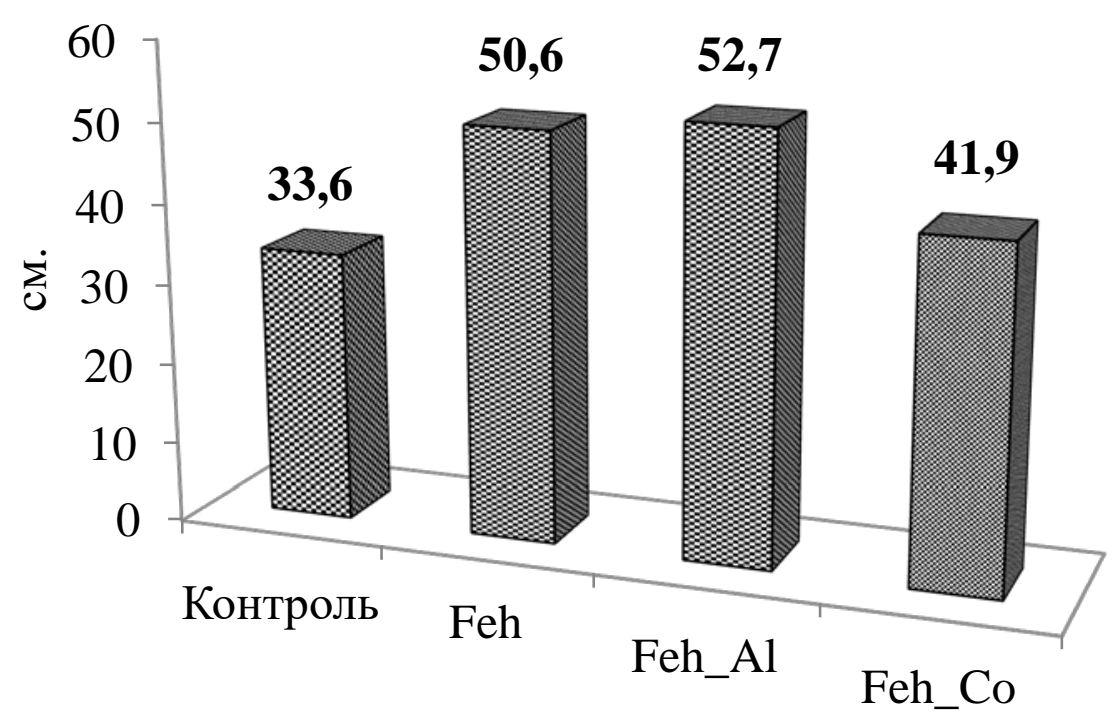

Варианты опыта

Puc. 4. Средняя длина побегов, сентябрь 2018 г.

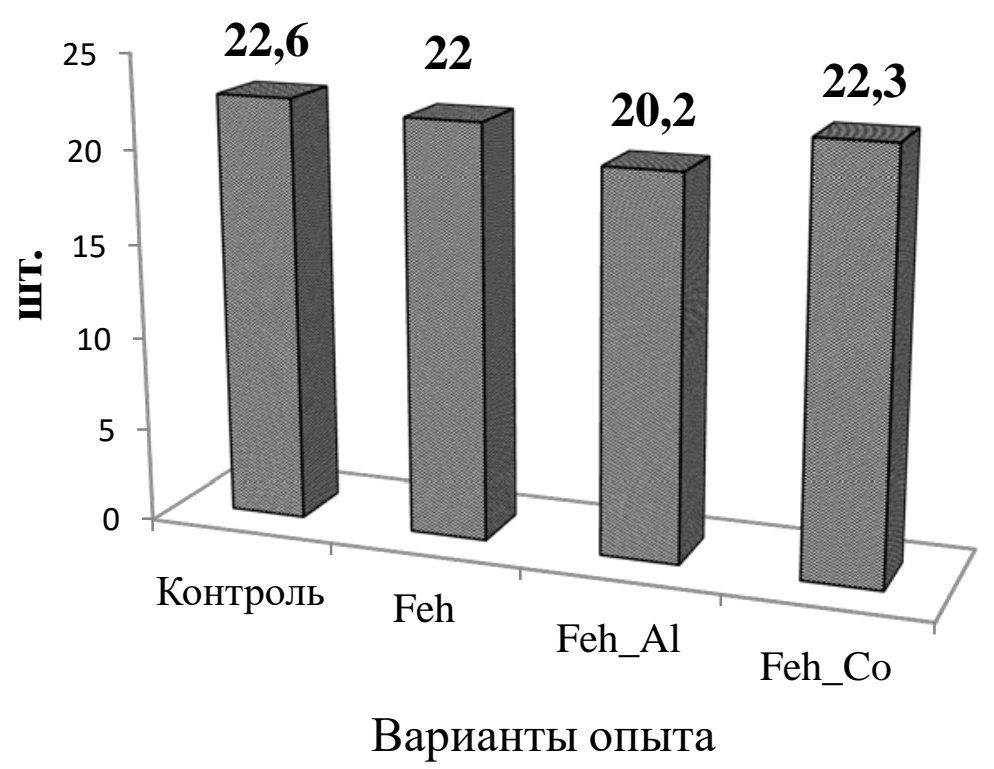

Pис. 5. Среднее количество корней, сентябрь 2018 2.

Параметры среднего количества корней 20,2-22,3 шт. ниже контрольной делянки, но данный биометрический показатель саженцев не оказал значительного влияния на качество посадочного материала. Длина корней не учитывалась, так как наблюдалось значительное ее развитие.

Благоприятные зимние условия положительно повлияли на перезимовку окорененных черенков - сохранность составила $100 \%$. В сен- тябре 2018 г. провели учет качества посадочного материала, результаты которого отражены на рисунке 6.

Больший процент стандартных саженцев получен при использовании растворов наночастиц 75-100\% растений 1-го и 2-го товарных сортов. На контрольном варианте было получено 52,6 \% качественного посадочного материала и 47,4 \% нестандартных саженцев, требующих доращивания в следующем году. 


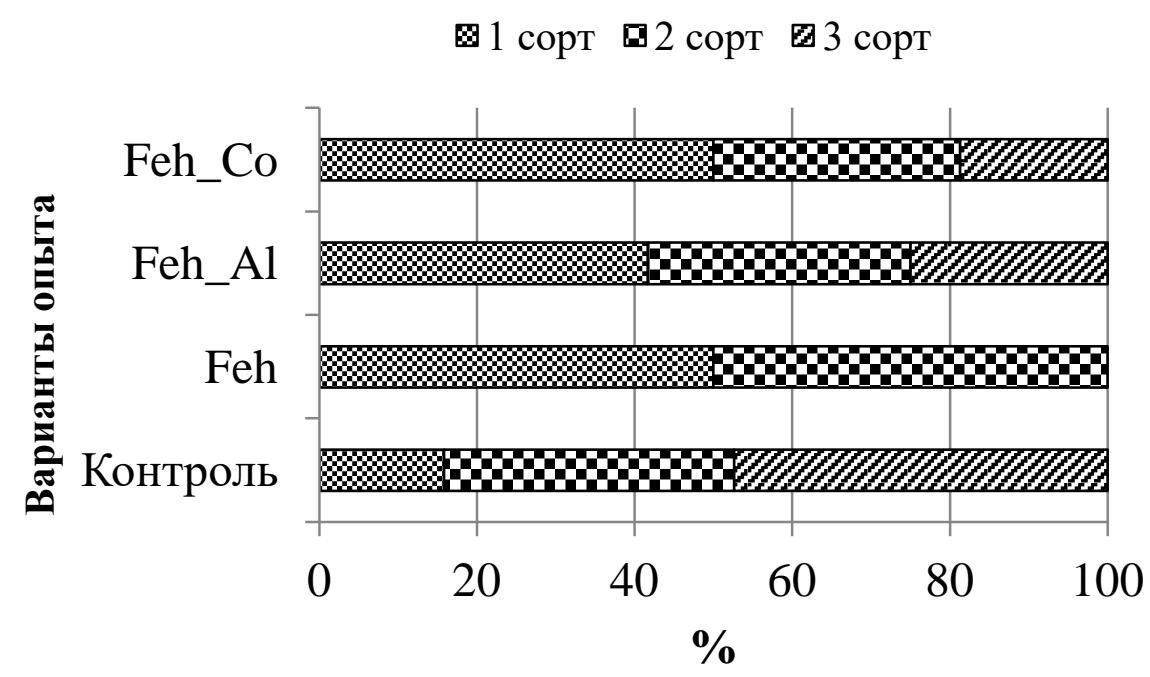

Pис. 6. Качество посадочного материала смородины черной, сентябрь 2018 г.

Можно отметить, что больший процент окоренения черенков на контрольном варианте в первый год выращивания оказался нивелированным после доращивания их в открытом грунте. Это относится ко всем вариантам обработки черенков наночастицами.

Выводы. Таким образом, среди изучаемых модификаций наночастиц биогенного ферригидрита выделяется вариант ИУК+Feh_Co, с использованием которого процент окоренения и качество посадочного материала были наибольшими по сравнению с контролем и другими вариантами опыта: ризогенез составил $100 \%$, выход саженцев товарных сортов - 81,3\%, из них $50 \%$ - 1-й сорт и 31,3 \% - 2-й сорт. Эффрективность наночастиц Feh и Feh_Al может быть увеличена путем подбора концентраций и времени экспозиции черенков в растворах с индолил-3-уксусной кислотой.

\section{Литература}

1. Тарасова Е.Ю., Коростелева В.П., Пономарев В.Я. Применение нанотехнологий в сельском хозяйстве // Вестн. Казан. технолог. унта. - 2012. - T. 15, № 21. - С. 121-122.

2. Сучкова С.А., Астафрурова Т.П. Морфологические изменения в черенках смородины черной под влиянием наночастиц оксида цинка // Роль физиологии и биохимии в интродукции и селекции овощных, плодовоягодных и лекарственных растений: мат-лы
III междунар. конф. - М.: Изд-во РУДН, 2017. - C. 312-315.

3. Бопn В.Л., Гуревич Ю.Л., Мистратова Н.А., Теремова М.И. Влияние ауксинов и наночастиц биогенного ферригидрита на окоренение и корнеобразование зеленых черенков вишни степной // Вестн. Курской гос. с.-Х. акад. - 2018. - № 5. - С. 72-76.

4. Аладина О.Н. Оптимизация технологии зеленого черенкования садовых растений // Изв. ТСХА. - 2013. - Вып. 4. - С. 5-22.

5. Колесникова В.Л., Кузьмина Е.М. Садоводство Сибири. - Красноярск, 2006. - 324 с.

6. Боnп В.Л., Мистратова Н.А., Петраковская Э.А. и др. Влияние наночастиц биогенного ферригидрита на укоренение одревесневших черенков ивы Ледебура // Биофизика. - 2018. - Т. 63, № 4. - С. 786-794.

7. Тарасенко М.Т. Зеленое черенкование садовых и лесных культур. - М.: Изд-во MCXA, 1991. - $272 \mathrm{c}$.

8. Моисейченко В.Ф. Методика опытного дела в плодоводстве и овощеводстве. - Киев: Выщ. шк., 1998. - 141 c.

9. ГОСТ Р 53135-2008. Посадочный материал плодовых, ягодных, субтропических, орехоплодных, цитрусовых культур и чая. - М.: Стандартинформ, 2009.

10. ГОСТ 26423-85. Почвы. Методы определения удельной электрической проводимости, $\mathrm{pH}$ и плотного остатка водной вытяжки. M., 1986. 
11. ГОСТ 26488-85. Определение нитртатов по методу ЦИНАО. - М., 1986.

12. ГОСТ 26489-85. Определение обменного аммония по методу ЦИНАО. - М., 1986.

13. ГОСТ 26204-91. Определение подвижных соединений фоссрора и калия по методу Чирикова в модификации ЦИНАО. - М., 1992.

14. Доспехов В.А. Методика полевого опыта. М.: Агропромиздат, 1985. - 351 с.

15. Гамзиков Г.П. Практические рекомендации по почвенной диагностике азотного питания полевых культур и применению удобрений в сибирском земледелии. - М.: Росинформагротех, 2018. - 48 c.

16. Крупкин П.И. Черноземы Красноярского края / Краснояр. гос. аграр. ун-т. - Красноярск, 2002. - С. 166-198.

17. Бугаков П.С., Чупрова В.В. Агрохимическая характеристика почв земледельческой зоны Красноярского края / Краснояр. гос. аграр. ун-т. - Красноярск, 1995. - С. 143.

18. Рудой Н.Г. Агрохимия почв Средней Сибири / Краснояр. гос. аграр. ун-т. - Красноярск, 2003. - 167 с.

\section{Literatura}

1. Tarasova E.Yu, Korosteleva V.P., Ponomarev V.Ya. Primenenie nanotekhnologij $v$ sel'skom hozyajstve // Vestn. Kazan. tekhnolog. un-ta. 2012. - T. 15, № 21. - S. 121-122.

2. Suchkova S.A., Astafurova T.P. Morfologicheskie izmeneniya $v$ cherenkah smorodiny chernoj pod vliyaniem nanochastic oksida cinka // Rol' fiziologii i biohimii v introdukcii i selekcii ovoshchnyh, plodovo-yagodnyh i lekarstvennyh rastenij: mat-ly III mezhdunar. konf. - M.: Iz-dvo RUDN, 2017. - S. 312-315.

3. Bopp V.L., Gurevich YU.L., Mistratova N.A., Teremova M.I. Vliyanie auksinov i nanochastic biogennogo ferrigidrita na okorenenie i korneobrazovanie zelenyh cherenkov vishni stepnoj // Vestn. Kurskoj gos. s.-h. akad. 2018. - № 5. - S. 72-76.

4. Aladina O.N. Optimizaciya tekhnologii zelenogo cherenkovaniya sadovyh rastenij // Izv. TSKHA. - 2013. - Vyp. 4. - S. 5-22.
5. Kolesnikova V.L., Kuz'mina E.M. Sadovodstvo Sibiri. - Krasnoyarsk, 2006. - 324 s.

6. Bopp V.L., Mistratova N.A., Petrakovskaya E.A. i dr. Vliyanie nanochastic biogennogo ferrigidrita na ukorenenie odrevesnevshih cherenkov ivy Ledebura // Biofizika. 2018. - T. 63, № 4. - S. 786-794.

7. Tarasenko M.T. Zelenoe cherenkovanie sadovyh i lesnyh kul'tur. - M.: Izd-vo MSKHA, 1991. - $272 \mathrm{~s}$.

8. Moisejchenko V.F. Metodika opytnogo dela v plodovodstve i ovoshchevodstve. - Kiev: Vyshch. shk., 1998. - $141 \mathrm{~s}$.

9. GOST R 53135-2008. Posadochnyj material plodovyh, yagodnyh, subtropicheskih, orekhoplodnyh, citrusovyh kul'tur i chaya. M.: Standartinform, 2009.

10. GOST 26423-85. Pochvy. Metody opredeleniya udel'noj elektricheskoj provodimosti, $\mathrm{rN}$ i plotnogo ostatka vodnoj vytyazhki. - M., 1986.

11. GOST 26488-85. Opredelenie nitrtatov po metodu CINAO. - M., 1986.

12. GOST 26489-85. Opredelenie obmennogo ammoniya po metodu CINAO. - M., 1986.

13. GOST 26204-91. Opredelenie podvizhnyh soedinenij fosfora i kaliya po metodu CHirikova v modifikacii CINAO. - M., 1992.

14. Dospekhov V.A. Metodika polevogo opyta. M.: Agropromizdat, 1985. - $351 \mathrm{~s}$.

15. Gamzikov G.P. Prakticheskie rekomendacii po pochvennoj diagnostike azotnogo pitaniya polevyh kul'tur i primeneniyu udobrenij $\mathrm{v}$ sibirskom zemledelii. - M.: Rosinformagrotekh, 2018. $-48 \mathrm{~s}$.

16. Krupkin P.I. CHernozemy Krasnoyarskogo kraya / Krasnoyar. gos. agrar. un-t. - Krasnoyarsk, 2002. - S. 166-198.

17. Bugakov P.S., CHuprova V.V. Agrohimicheskaya harakteristika pochv zemledel'cheskoj zony Krasnoyarskogo kraya I Krasnoyar. gos. agrar. un-t. - Krasnoyarsk, 1995. - S. 143.

18. Rudoj N.G. Agrohimiya pochv Srednej Sibiri / Krasnoyar. gos. agrar. un-t. - Krasnoyarsk, 2003. -167 s. 